\title{
Development of Analyzer for Photoluminescence Quenching in a Solid Matrix
}

\author{
Hidenobu SHIROISHI ${ }^{*}$, Kazuhisa SUZUKI ${ }^{\mathrm{a}}$, Michiko SEO ${ }^{\mathrm{a}}$, \\ Sumio TOKITA ${ }^{\mathrm{b}}$ and Masao KANEKO ${ }^{\mathrm{a}, \ddagger}$
}

\author{
${ }^{a}$ Faculty of Science, Ibaraki University, Bunkyo 2-1-1, Mito, Ibaraki 310-8512, Japan \\ ${ }^{\mathrm{b}}$ Faculty of Engineering, Saitama University, Saitama, Saitama 338-8570, Japan \\ *e-mail: cpx26485@mopera.ne.jp
}

(Received: November 30, 2001; Accepted for publication: January 24, 2002; Published on Web: March 22, 2002)

An analyzer called "Q-chanG4" was developed with Visual Basic for photoluminescence quenching in a solid. This software can analyze the quenching mechanism in a solid matrix using emission decay curves and Stern-Volmer plots. Photoluminescence quenching of Tris(2,2'-bipyridine)ruthenium(II) in a polyethylene glycol solid by methylviologen was analyzed with Q-chanG4. The quenching mechanism was determined as a combination of a dynamic quenching and a static quenching involving multi-step equilibria and dynamic quenching. The dynamic quenching rate constant in the polyethylene glycol was as large as that in an aqueous solution, suggesting that the diffusion coefficient of molecules in the polyethylene glycol is almost the same as that in an aqueous solution in spite of the solid state.

Keywords: Q-chanG4, emission, photoluminescence quenching, analyzer, polyethylene glycol, methylviologen, $\mathrm{Ru}(\mathrm{bpy})_{3}{ }^{2+}$, solid

\section{Introduction}

Electron transfer reactions at the photoexcited state of a sensitizer molecule are attracting attention for various applications such as energy conversion devices [1-3], photochemical sensors [4-6] and photochemical synthesis. Solid matrixes, e.g., macromolecules, clays and zeolites are useful as a matrix to construct practical devices. Photoinduced electron transfer in a solid matrix is different from that in a solution since diffusion and convection of molecules are suppressed in the matrix.

The excited state of a molecule created by absorption of irradiation returns to the ground state via emission or non-radiative processes. The emission from the excited state of the molecule is influenced by the microenvironment around the molecule and coexisting molecules. This feature is utilized in an emission probe method. We can obtain information about the microenvironment around the probe, electron transfer or energy transfer processes, and coexisting molecules by this method. This method is also useful for quantitative analysis because the sensitivity of emission spectrometry is higher than that of absorption spectrometry.

$\ddagger$ Correspondence to be addressed
Photochemical quenching processes in polymer matrixes have been reported by our group [7-11] and others $[4,13]$. In such a system, the excited state of the molecule is quenched not only by the collision with the quencher molecule (dynamic mechanism) but also by a static mechanism arising from the overlap of the molecular orbital (or electron tunneling effect) for which both reactants do not diffuse during the quenching event. The analysis of Stern-Volmer plots is effective to determine the quenching mechanism. However, not all quenching mechanisms could be determined only by analyzing Stern-Volmer plots because experimental data can sometimes be fitted by more than one model, and convergence can be attained with different parameters when using a non-linear least square method. In these cases, we have to search a series of parameters with which the equation for the model can reproduce the experimental decay curves. To the contrary, kinetic parameters of a photochemical quenching can be estimated by analysis of the emission decay curves. It is now useful to develop a new system with which the quenching mechanism in a solid matrix can be analyzed using both methods effectively. 
In the present study, a program for the analysis of the photochemical quenching mechanism in a solid matrix, called "Q-chanG4", was developed using Visual Basic. We have derived theoretical equations of emission decay curves in a solid matrix for thirteen models. This program can analyze the quenching behavior with emission decay curves and Stern-Volmer plots using a Gauss-Newton method.

\section{Quenching mechanisms in a solid matrix}

Figure 1 shows the schematic representation of a photochemical energy diagram and the kinetic parameters of each process. The return from a photoexcited state to the ground state is represented by three separated processes: (1) Radiationless deactivation $\left(k_{n r}\right)$, (2) Photoluminescence $\left(k_{e}\right)$, and (3) Quenching $\left(k_{q 1}\right.$ and $\left.k_{q 2}\right)$. The following decay functions $I(t)$ in each model were normalized in such a way that $I(0)=1$.

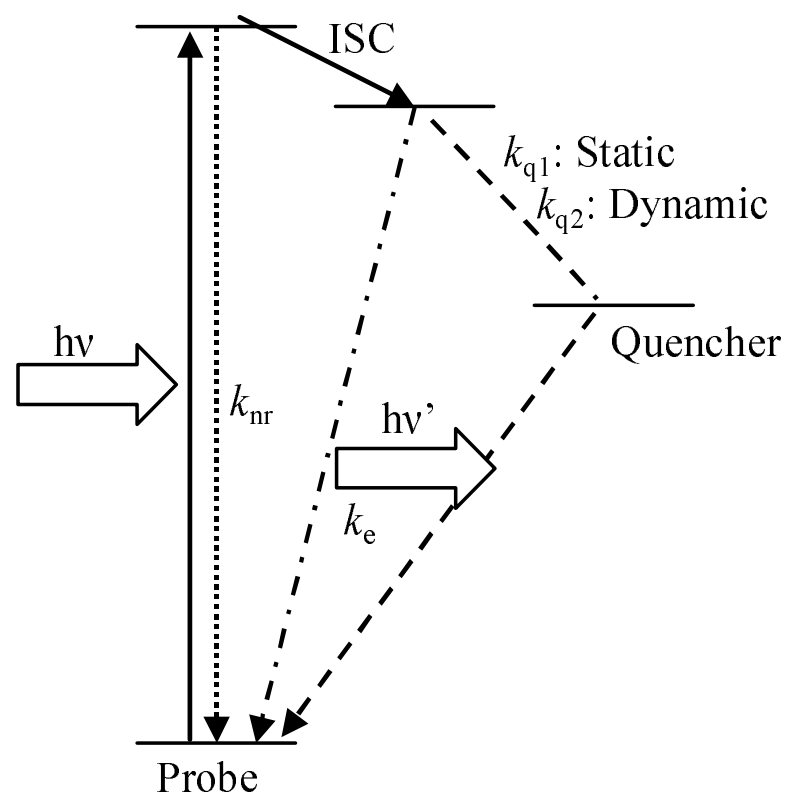

Figure 1. Photochemical energy diagram and kinetic parameters of photochemical processes. $k_{n r}\left(\mathrm{~s}^{-1}\right)$ is a nonradiative rate constant, $k_{e}\left(\mathrm{~s}^{-1}\right)$ is an emission rate constant, $k_{q 1}\left(\mathrm{~s}^{-1}\right)$ is a static-quenching rate constant, $k_{q 2}$ $\left(\mathrm{mol}^{-1} \mathrm{dm}^{3} \mathrm{~s}^{-1}\right)$ is a dynamic-quenching rate constant.

\subsection{Dynamic Quenching Mechanism}

\section{Model 1}

This is a conventional dynamic quenching model where the Stern-Volmer plot shows a linear relationship
[12]. The decay rate of the photoexcited probe molecule is expressed as:

$$
-\frac{d\left[^{*} P\right]}{d t}=k_{n r}\left[{ }^{*} P\right]+k_{e}\left[{ }^{*} P\right]+k_{q 2}\left[{ }^{*} P\right]\left[Q_{t}\right]
$$

where $\left[{ }^{*} P\right]$ is the concentration of the emission probe in the excited state, $\left[Q_{t}\right]\left(\mathrm{mol} \mathrm{dm}{ }^{-3}\right)$ is the concentration of the quencher. Emission lifetime at $\left[Q_{t}\right]=0, \tau_{0}(\mathrm{~s})$ is represented as:

$$
\tau_{0}=1 /\left(k_{n r}+k_{e}\right)
$$

The emission decay curves in a solid matrix are often observed as a multi-exponential function:

$$
I(t)=\sum_{n} A_{n} \exp \left(-t / \tau_{0, n}\right) \quad\left(\sum_{n} A_{n}=1\right)
$$

where $\tau_{0, n}(\mathrm{~s})$ is the emission lifetime at $\left[Q_{t}\right]=0$, and $A_{n}$ is the pre-exponential factor of $n$-th component. The function of the emission decay curves for model 1 is derived from eqs. 1 - 3 as eq. 4 .

$$
I(t)=\sum_{n} A_{n} \exp \left\{-\left(1 / \tau_{0, n}+k_{q 2}\left[Q_{t}\right]\right) t\right\}
$$

\subsection{Single-step equilibrium models}

These models consider single-step equilibrium between the emission probe and the quencher. Assuming that the association between the probe and the quencher is not too strong to change the molecular orbital of the excited state of the probe, the photochemical reactions considered in these models are shown below.

$$
\begin{gathered}
\mathrm{P}+\mathrm{Q} \stackrel{\mathrm{K}}{\rightleftharpoons}(\mathrm{P}-\mathrm{Q}), \quad K=\frac{[(P-Q)]}{[P][Q]} \\
\mathrm{P} \stackrel{h v}{\longrightarrow}{ }^{*} \mathrm{P} \\
{ }^{*} \mathrm{P} \stackrel{k_{e}}{\longrightarrow} \mathrm{P}+h v \\
{ }^{*} \mathrm{P} \stackrel{k_{n r}}{\longrightarrow} \mathrm{P} \\
{ }^{*} \mathrm{P}+\mathrm{Q} \stackrel{k_{q 2}[Q]}{\longrightarrow} \mathrm{P}+\mathrm{Q} \\
(\mathrm{P}-\mathrm{Q}) \stackrel{h v}{\longrightarrow}\left({ }^{*} \mathrm{P}-\mathrm{Q}\right)
\end{gathered}
$$

$$
\left({ }^{*} \mathrm{P}-\mathrm{Q}\right) \stackrel{k_{e}}{\longrightarrow}(\mathrm{P}-\mathrm{Q})+h \mathrm{v}^{\prime}
$$

$$
\left({ }^{*} \mathrm{P}-\mathrm{Q}\right) \stackrel{k_{n r}}{\longrightarrow}(\mathrm{P}-\mathrm{Q})
$$




$$
\left({ }^{*} \mathrm{P}-\mathrm{Q}\right) \stackrel{k_{q 1}}{\longrightarrow}(\mathrm{P}-\mathrm{Q})
$$

where $K$ is the equilibrium constant of the incorporation of the quencher into the quenching sphere, and (P - Q) shows $\mathrm{P}$ and $\mathrm{Q}$ present in a quenching sphere in which a static quenching takes place with the rate constant $k_{q 1}$.

\section{Model 2}

Model 2 takes into account all of the above reactions. The concentration of free quencher $([Q])$ is expressed as follows:

$$
\begin{aligned}
& {[Q]=\frac{1}{2 K} } {\left[\sqrt{\left(1-K\left[Q_{t}\right]+K\left[P_{t}\right]\right)^{2}+4\left[Q_{t}\right] K}\right.} \\
&\left.-\left(1-K\left[Q_{t}\right]+K\left[P_{t}\right]\right)\right]
\end{aligned}
$$

where $\left[P_{t}\right]$ is the total concentration of the probe. The function of the decay curves for model 2 is given by eq. 15 from eqs. $3,5-13$.

$$
\begin{aligned}
I(t)= & \sum_{n} \frac{A_{n}}{K[Q]+1}\left[\exp \left\{-\left(1 / \tau_{0, n}+k_{q 2}[Q]\right) t\right\}\right. \\
& \left.+K[Q] \exp \left\{-\left(1 / \tau_{0, n}+k_{q 1}\right) t\right\}\right]
\end{aligned}
$$

\section{Model 3}

In this model, the static quenching rate constant $\left(k_{q 1}\right)$ is much larger than the reciprocal number of emission lifetime at $\left[Q_{t}\right]=0\left(\tau_{0, n}\right)$. In this case, the function of emission decay curves is represented as:

$$
I(t)=\sum_{n} A_{n} \exp \left\{-\left(1 / \tau_{0, n}+k_{q 2}[Q]\right) t\right\}
$$

\section{Model 4}

This model is applied when the product of the dynamic quenching rate constant and the total quencher concentration $\left(k_{q 2}\left[Q_{t}\right]\right)$ is negligible. The function of the emission decay curves is expressed by eq. 17 .

$$
\begin{gathered}
I(t)=\sum_{n} \frac{A_{n}}{K[Q]+1}\left[\exp \left\{-t / \tau_{0, n}\right\}\right. \\
\left.+K[Q] \exp \left\{-\left(1 / \tau_{0, n}+k_{q 1}\right) t\right\}\right]
\end{gathered}
$$

\section{Model 5}

In this model, the $k_{q 1}$ is much larger than $1 / \tau_{0, n}$, and the diffusion of the molecules in the solid matrix is suppressed so that the dynamic quenching is negligible. $I(t)$ is expressed as follows:

$$
I(t)=\sum_{n} A_{n} \exp \left(-t / \tau_{0, n}\right)
$$

Since the decay curve is independent of the quencher concentration, photochemical parameters cannot be obtained from the analysis of emission decay curves.

\subsection{Multi-step equilibrium models (Poisson distribution models)}

Eq.19 to 24 were taken into account in the following Multi-step equilibrium models.

$$
\begin{gathered}
{[\mathrm{P}-(i-1) \mathrm{Q}]+\mathrm{Q} \stackrel{K_{i}}{\rightleftharpoons}(\mathrm{P}-i \mathrm{Q}),} \\
K_{i}=\frac{[(P-i Q)]}{[Q][P-(i-1) Q]} \\
\left(K_{i}=K_{1} / i\right) \quad(i=1,2,3, \cdots)
\end{gathered}
$$

$$
\mathrm{P} \stackrel{h v}{\longrightarrow}{ }^{*} \mathrm{P}
$$

$$
{ }^{*} \mathrm{P} \stackrel{k_{e}}{\longrightarrow} \mathrm{P}+h v
$$

$$
{ }^{*} \mathrm{P} \stackrel{k_{n r}}{\longrightarrow} \mathrm{P}
$$

$$
{ }^{*} \mathrm{P}+\mathrm{Q} \stackrel{k_{q 2}[Q]}{\longrightarrow} \mathrm{P}+\mathrm{Q}
$$

$$
(\mathrm{P}-i \mathrm{Q}) \stackrel{h v}{\longrightarrow}\left({ }^{*} \mathrm{P}-i \mathrm{Q}\right)
$$

$$
\left({ }^{*} \mathrm{P}-i \mathrm{Q}\right) \stackrel{k_{e}}{\longrightarrow}(\mathrm{P}-i \mathrm{Q})+h v^{\prime}
$$

$$
\left({ }^{*} \mathrm{P}-i \mathrm{Q}\right) \stackrel{k_{n r}}{\longrightarrow}(\mathrm{P}-i \mathrm{Q})
$$

$$
\left({ }^{*} \mathrm{P}-i \mathrm{Q}\right) \stackrel{k_{q I}}{\longrightarrow}(\mathrm{P}-i \mathrm{Q})
$$

where $k_{q I}$ is the static quenching rate constant, and equals $k_{q 1}$ in models 6 to 9 and $k_{q I}=i k_{q 1}$ in the models 10 and 11 .

\section{Model 6}

Assuming that the distribution of the emission probe and the quencher follows the Poisson distribution, the probability of existing $x$ quenchers in a quenching sphere $p(x)$ is expressed as: 


$$
\begin{gathered}
p(x)=\frac{m^{x}}{x !} \exp (-m) \\
\left(m=\frac{4 \pi\left\{r^{3}-s^{3}\right\}}{3} N_{A} 10^{-24}\left[Q_{t}\right]\right)
\end{gathered}
$$

where $r(\mathrm{~nm})$ is the radius of the quenching sphere, $s(\mathrm{~nm})$ is the radius of the excluded volume of the molecules, and $N_{A}$ is the Avogadro's number.

The function of the emission decay curves is expressed by eq. 25 .

$$
\begin{aligned}
I(t) & =\sum_{n} A_{n}\left[p(0) \exp \left\{-\left(1 / \tau_{0, n}+k_{q 2}[Q]\right) t\right\}\right. \\
& \left.+\{1-p(0)\} \exp \left\{-\left(1 / \tau_{n, 0}+k_{q 1}\right) t\right\}\right]
\end{aligned}
$$

The relationship between the equilibrium constant $\left(K_{1}\right)$ and the radius of the quenching sphere is represented by the following equation:

$$
K_{1}=4 \pi\left(r^{3}-s^{3}\right) N_{A} 10^{-24} / 3
$$

\section{Model 7}

Eq. 26 can be rewritten when the static quenching rate constant $\left(k_{q 1}\right)$ is much larger than the reciprocal of the emission lifetime at $\left[Q_{t}\right]=0\left(\tau_{0, n}\right)$ as follows:

$$
I(t)=\sum_{n} A_{n} \exp \left\{-\left(1 / \tau_{0, n}+k_{q 2}[Q]\right) t\right\}
$$

\section{Model 8}

When the dynamic quenching rate constant $\left(k_{q 2}\right)$ is much smaller than $1 / \tau_{0, n}, I(t)$ is represented as follows:

$$
\begin{gathered}
I(t)=\sum_{n} A_{n}\left[p(0) \exp \left(-t / \tau_{0, n}\right)\right. \\
\left.+\{1-p(0)\} \exp \left\{-\left(1 / \tau_{0, n}+k_{q 1}\right) t\right\}\right]
\end{gathered}
$$

\section{Model 9 (Conventional static quenching model)}

This model can be applied in the case where $k_{q 1}$ is much larger than $1 / \tau_{0, n}$ and $k_{q 2}[Q]$ is negligible. $I(t)$ is expressed as:

$$
I(t)=\sum_{n} A_{n} \exp \left(-t / \tau_{0, n}\right)
$$

This equation is so-called Perrin equation [13]. Eq. 29 does not contain the quencher concentration, so that the emission decay curves does not change with increasing quencher concentration.

\section{Model 10}

In this model, the static quenching rate constant is proportional to the number of the quencher in the quenching sphere $\left(k_{q I}=i k_{q 1}\right) . I(t)$ is expressed as

$$
\begin{aligned}
I(t) & =\sum_{n} A_{n}\left[p(0) \exp \left\{-\left(1 / \tau_{0, n}+k_{q 2}[Q]\right) t\right\}\right. \\
& \left.+\sum_{i=1}^{\infty} p(i) \exp \left\{-\left(1 / \tau_{0, n}+i k_{q 1}\right) t\right\}\right]
\end{aligned}
$$

\section{Model 11}

Eq. 31 can be applied when the dynamic quenching mechanism is negligible.

$$
\begin{gathered}
I(t)=\sum_{n} A_{n}\left[p(0) \exp \left(-t / \tau_{0, n}\right)\right. \\
\left.+\sum_{i=1}^{\infty} p(i) \exp \left\{-\left(1 / \tau_{0, n}+i k_{q 1}\right) t\right\}\right]
\end{gathered}
$$

\subsection{Two-site dynamic quenching models [4]}

In these models reported by Carraway et al., it is assumed that two regions with different diffusion coefficients exist in a solid matrix, which causes different second-order quenching rates $\left(k_{q 21}\right.$ and $\left.k_{q 22}\right)$.

\section{Model 12}

In the model, $I(t)$ is represented as:

$$
\begin{gathered}
I(t)=f_{1} \exp \left\{-\left(1 / \tau_{0}+k_{q 21}\left[Q_{t}\right]\right) t\right\} \\
+f_{2} \exp \left\{-\left(1 / \tau_{0}+k_{q 22}\left[Q_{t}\right]\right) t\right\}
\end{gathered}
$$

where, $f_{1}$ and $f_{2}$ are the fractions of the different regions.

\section{Model 13}

This model can be applied in the case where $k_{q 22}$ is neglected because of slow diffusion in region 2. $I(t)$ is represented as follows:

$$
\begin{gathered}
I(t)=f_{1} \exp \left\{-\left(1 / \tau_{0}+k_{q 21}\left[Q_{t}\right]\right) t\right\} \\
+f_{2} \exp \left(-t / \tau_{0}\right)
\end{gathered}
$$

The summary of these models is shown in Table 1. 
Table 1. Summary of quenching mechanisms and kinetic parameters

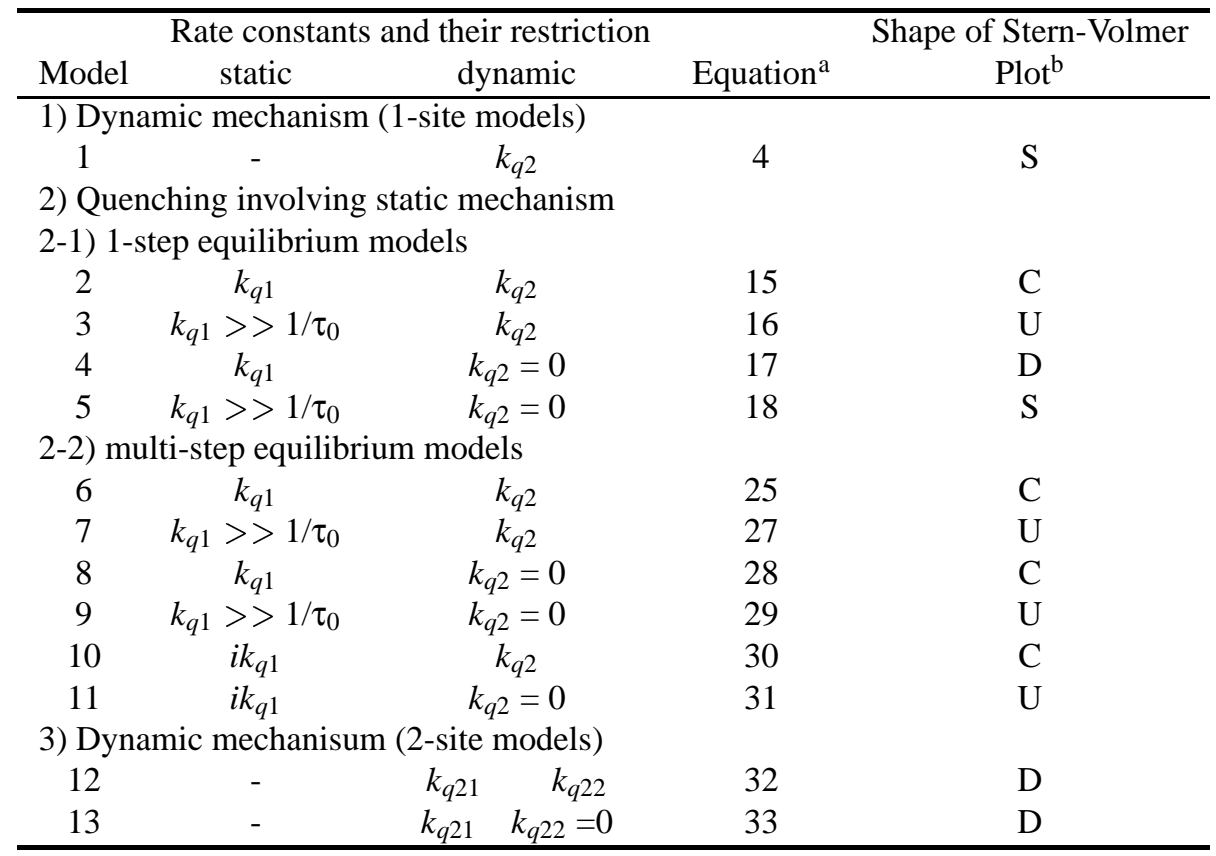

a) The corresponding decay curve equation is shown in the text.

b) S, straight line; U, upward deviating curve; D, downward deviating curve; C, complicated curve

c) The corresponding quenching system to which the mechanism is applicable.
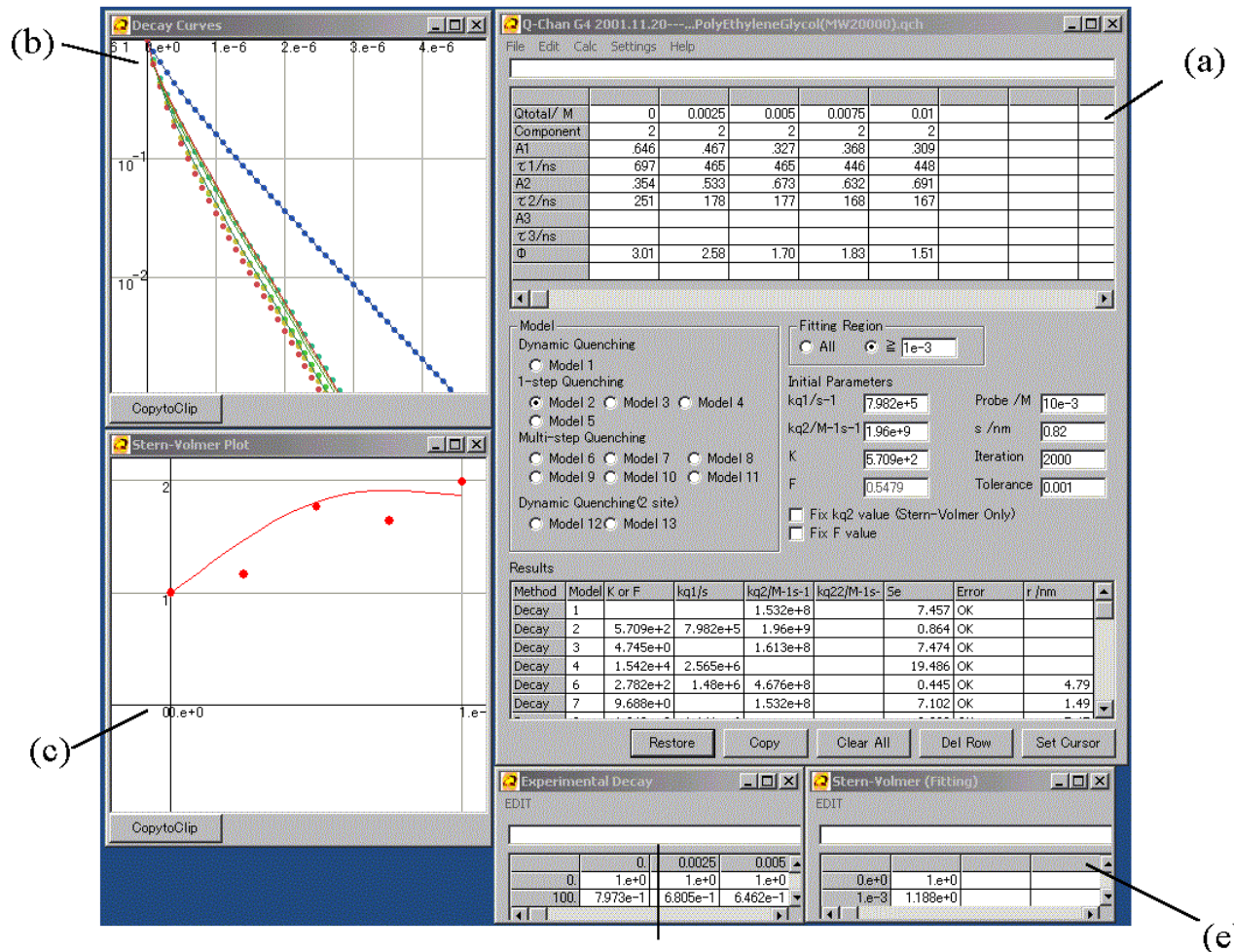

(d) (a)

(e)

Figure 2. Screen shot of Q-chanG4. (a) Main window. (b) Graph window of emission decay curves. (c) Stern-Volmer plot window. (d) Numerical values calculated by a theoretical equation. (e) Numerical values of experimental emission decay curves. 


\section{Implementation}

We used an IBM-PC/AT compatible (HITACHI) in which Microsoft Windows 2000 was installed for developing "Q-chanG4" with the Microsoft Visual Basic version 6(SP5). The program was tested with Windows 98, Me, NT4, 2000 and XP installed in IBM/PC-AT compatibles and PC-9821.

\section{Feature of Q-chanG4}

The commands of Q-chanG4 are listed in Table 2. Figure 2 shows the screen shot of Q-chanG4. Q-chanG4 is equipped with the following two methods for the analysis of the quenching mechanisms.

\subsection{Usage}

\subsubsection{Analysis of Emission Decay Curves at Various Quencher Concentrations}

1. You must measure emission decay curves at various concentrations of the quencher to estimate lifetimes and other parameters.

2. Run Q-chanG4.exe, and input these parameters into the upper table of Q-chanG4.

3. Normalize $A$ values by selecting $[\mathrm{Calc}] \rightarrow$ [Normalization]. Then, emission decay curves and numerical values are displayed in new windows.

4. Select a model, and input the initial parameters (see Table 3).

5. The decay curve analysis by the Gauss-Newton method will start when you select [Calc] $\rightarrow$ [decay curve analysis]. Since the analysis by GaussNewton method often diverges, you must watch carefully whether there is "*" in the "Error" column. If you obtain it, please try another initial parameters. If you have "not saturated" in the "Error" column, you must input a bigger number in "Iteration" textbox.

6. After the analysis, the parameters are shown in the lower table; rate constants, equilibrium constant, and the sum of squared residual $\left(S_{e}\right)$ or coefficient of determination $\left(R^{2}\right)$ defined by:

$$
R^{2}=1-\frac{S_{e}}{S_{y y}}
$$

where $S_{y y}$ is the sum of squared deviation.

\subsubsection{Analysis of Stern-Volmer Plot}

1. You must input the relative emission yields at the various concentrations of the quencher in the upper table.

2. Input the parameters of the decay curve at $0 \mathrm{~mol}$ $\mathrm{dm}^{-3}$ in the first column in the upper table.

3. Select a model, and input initial parameters for Gauss-Newton method.

4. If you calculate the $k_{q 2}$ value based on the decline of $\tau_{0} / \tau$ plots vs. $\left[Q_{t}\right]$, input the $k_{q 2}$ value into the textbox for $k_{q 2}$, and check the "Fix kq2 value".

5. The calculation will start when you select [Calc][Stern-Volmer analysis].

6. Then you have a result in the lower table of the main window. If you have "*" in the "Error" column, please try another initial parameter.

\section{Analysis of Phosphorescence Quenching in polyethylene glycol using Q-chanG4}

The phosphorescence quenching in polyethylene glycol $(\mathrm{MW}=20,000)$ was analyzed with Q-chanG4. Tris(2,2'bipyridine)ruthenium(II) $\left(\mathrm{Ru}(\mathrm{bpy})_{3}{ }^{2+}\right)$ and methylviologen (abbreviated to $\mathrm{MV}^{2+}$ ) were utilized as an emission probe and a quencher, respectively.

\subsection{Experimental}

$\mathrm{Ru}(\mathrm{bpy})_{3}{ }^{2+}$ and $\mathrm{MV}^{2+}$ were dissolved in a $5 \mathrm{wt} \%$ polyethylene glycol aqueous solution. Then $100 \mathrm{~mm}^{3}$ of the mixture solution was spread onto a pre-cleaned slide glass (Matsunami S-0313). The film was dried under vacuum for $3 \mathrm{~h}$ at $25^{\circ} \mathrm{C}$. The concentration of $\mathrm{Ru}(\mathrm{bpy})_{3}{ }^{2+}$ in the film is $20 \mathrm{mmol} \mathrm{dm}{ }^{-3}$. The sample film was placed in a quartz cell diagonally. The emission was monitored from the backside of the glass plate to minimize the scattering effect. All the measurements were carried out under Ar. Emission spectra were measured with a spectrofluorometer (Shimadzu RF-5300 with Hamamatsu photonics photomultiplier R928-08), and emission decay was measured with a time-correlated singlephoton counting apparatus (Hitachi-Horiba NAES-550) equipped with a nitrogen lamp (10 atm) at $20^{\circ} \mathrm{C}$. 
Table 2. Command in Q-chanG4.

\begin{tabular}{|c|c|c|}
\hline \multicolumn{2}{|c|}{ Menu/Submenu } & Description \\
\hline \multicolumn{3}{|c|}{ File } \\
\hline & New & Clear All the quenching data. \\
\hline & Open & Read the quenching data in Q-chanG4 format. \\
\hline & Save As & Save the quenching data in Q-chanG4 format. \\
\hline & Quit & Quit Q-chanG4. \\
\hline \multicolumn{3}{|l|}{ Calc } \\
\hline & Normalization & Normalize the pre-exponential parameters $\left(A_{n}\right)$ \\
\hline & Decay curve Analysis & Analyze the decay curves with Gauss-Newton method. \\
\hline & Calc decay curves with input param. & Calculate the decay curves with input parameters. \\
\hline & Stern-Volmer ananlysis & Analyze the Stern-Volmer plot with Gauss-Newton method. \\
\hline & Calc Stern-Volmer with input param. & Calculate the Stern-Volmer plot with input parameters. \\
\hline \multicolumn{3}{|l|}{ Settings } \\
\hline & Set Parameters & Settings for output format and Gauss-Newton method \\
\hline \multicolumn{3}{|l|}{ Help } \\
\hline & Help & Show help file. (English and Japanese) \\
\hline & About & Show information about Q-chanG4. \\
\hline
\end{tabular}

Table 3. Parameters used for the analysis.

\begin{tabular}{lll}
\hline Parameter & Description & Restriction \\
\hline$k_{q 1} / \mathrm{s}$ & Static quenching rate constant & $k_{q 1}>0$ \\
$k_{q 2} / \mathrm{mol}^{-1} \mathrm{dm}^{3} \mathrm{~s}^{-1}$ & Dynamic quenching rate constant & $k_{q 2}>0$ \\
$K$ & Equilibrium constant & $K>0$ \\
$F$ & $F$ value $\left(=f_{2} / f_{1}\right)$ using model 12 and 13 & $F>0$ \\
Probe $/ \mathrm{M}$ & The concentration of probe $\left(C_{p}\right)$ & $C_{p}>0$ \\
$s / \mathrm{nm}$ & The radius of the excluded volume of the redox center & $s>0$ \\
Iteration & The number of maximum iteration & Iteration $>0$ \\
Tolerance & The condition to end the regression process & Tolerance $>0$ \\
\hline
\end{tabular}

\subsection{Results and Discussion}

Figure 3 shows the corrected emission spectra of $\mathrm{Ru}(\mathrm{bpy}) 3_{3}{ }^{2+}$ in polyethylene glycol and water. The maximum of the spectrum in polyethylene glycol shifts to higher energies by $920 \mathrm{~cm}^{-1}$ than that in the aqueous solution. This would be because the dielectric constant of polyethylene glycol is lower than that of water to destabilize the excited state of the probe. Another possible reason is the luminescence rigidochromism caused by the slow reorientation of adjacent molecules (solvent molecules and counter ions)[14]. The lifetime of $\mathrm{Ru}(\mathrm{bpy}) 3^{2+}$ in polyethylene glycol is similar to that in an aqueous solution (664 ns). Since the lifetime of the phosphorescence in a rigid environment becomes longer than that in a solution, the reason for the blue shift would be attributed to the lower dielectric constant.

Table 4 shows the result of the lifetime decay analysis for $\mathrm{Ru}(\mathrm{bpy})_{3}{ }^{2+}$ in polyethylene glycol. The phosphorescence decay curves in polyethylene glycol were bi-exponential curves that have been often observed in heterogeneous systems $[11,14]$.

Table 5 shows the parameters obtained by the analysis of the emission decay curves and the sum of squared residual calculated with the theoretical equations of the Stern-Volmer plot with the parameter [11].

On the basis of the sum of squared residual, phosphorescence behavior in polyethylene glycol can be explained with models 10 and 6 considering Poisson type static quenching and dynamic quenching mechanisms. Although it is difficult to determine the most suitable model between models 10 and 6, the decay curves are well simulated by model 10 (Figure 4 ). Since the precision of emission intensity is lower than that of lifetime measurement in the film system, model 10 would be suitable to describe the quenching mechanism in polyethylene glycol.

The dynamic quenching rate constant in polyethylene glycol is almost the same as that in an aqueous solution, suggesting that the collision frequency in polyethylene glycol is as high as that in water despite the solid matrix. 


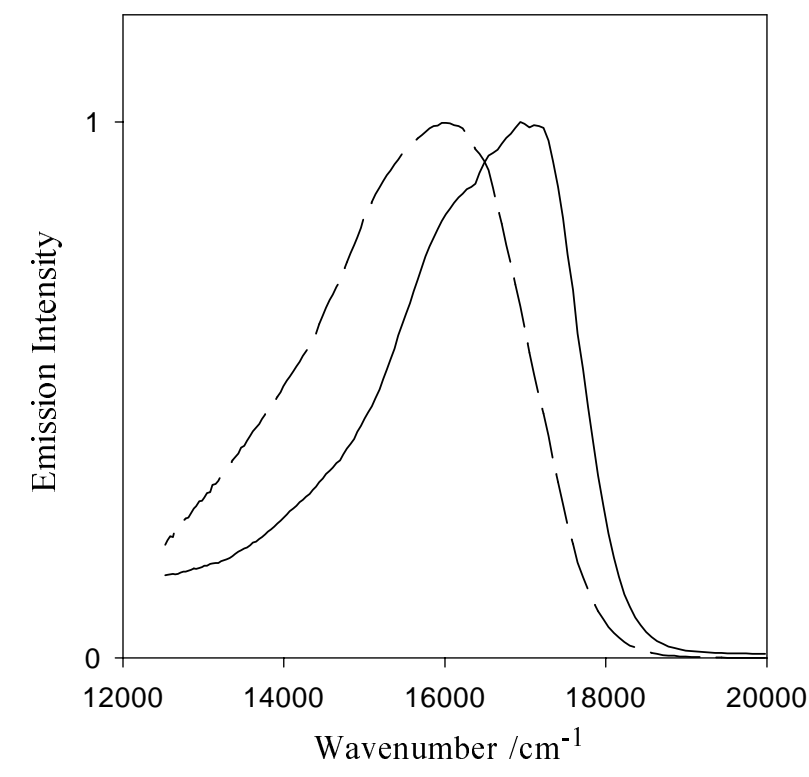

Figure 3. Corrected emission spectra of $\mathrm{Ru}(\mathrm{bpy})_{3}{ }^{2+}$. in polyethylene glycol; ---, in $\mathrm{H}_{2} \mathrm{O}$.
Table 4. Analysis of lifetime decay curves for Ru(bpy) $3^{2+}$ in polyethylene glycol.

\begin{tabular}{cccccc}
\hline $\mathrm{MV}^{2+}$ & \multicolumn{3}{c}{ Component 1 } & \multicolumn{3}{c}{ Component 2 } & $\chi^{2}$ \\
$/ 10^{-3} \mathrm{~mol} \mathrm{dm}^{-3}$ & $A_{1}$ & $\tau_{1}$ & $A_{2}$ & $\tau_{2}$ & \\
\hline 0.0 & 0.646 & 697 & 0.354 & 251 & 1.21 \\
2.5 & 0.467 & 465 & 0.533 & 178 & 1.06 \\
5.0 & 0.327 & 465 & 0.673 & 177 & 1.22 \\
7.5 & 0.368 & 446 & 0.632 & 168 & 1.18 \\
10.0 & 0.309 & 448 & 0.691 & 167 & 1.07 \\
\hline
\end{tabular}

Table 5. Result of decay curve analysis.

\begin{tabular}{cccccccc}
\hline Model & $\mathrm{K}$ or $\mathrm{F}$ & $k_{q 1} / 106 \mathrm{~s}$ & $k_{q 2} / 10^{7} \mathrm{M}^{-1} \mathrm{~s}^{-1}$ & $k_{q 22} / 10^{7} \mathrm{M}^{-1} \mathrm{~s}^{-1}$ & $S_{e}$ & $r / \mathrm{nm}$ & $S_{e}($ Stern-Volmer $)$ \\
\hline 10 & 244.9 & 0.81 & 62.6 & 0.35 & 4.6 & 0.20 \\
6 & 278.2 & 1.48 & 46.8 & 0.45 & 4.8 & 0.18 \\
2 & 570.9 & 0.80 & 196. & 0.86 & & 0.18 \\
8 & 1043. & 1.14 & & 0.90 & 7.5 & 1.03 \\
12 & 0.55 & & 15.2 & 254.4 & 7.00 & & 1.12 \\
7 & 9.69 & & 15.3 & & 7.10 & 1.6 & 0.12 \\
11 & 469.3 & 0.52 & & 7.13 & 5.7 & 1.08 \\
1 & & & 15.3 & 7.46 & & 0.16 \\
3 & 4.75 & & 16.1 & 7.47 & & 0.12 \\
13 & 0.55 & & 15.7 & 7.65 & & 0.71 \\
4 & 15420. & 2.57 & & 19.49 & & 0.17 \\
\hline
\end{tabular}

\section{Conclusion}

We have developed a photoluminescence quenching analyzer called Q-chanG4 with Visual Basic. Quenching mechanisms in a solid matrix can be analyzed with the software using emission decay curves and a SternVolmer plot. Model 10 considering Poisson distribution type static quenching and dynamic quenching explains the quenching behavior in polyethylene glycol.

\section{Agreements for using the pro- gram}

The "Q-chanG4" is freeware. We cannot be responsible for damages that you might receive when using this program. Please feel free to contact us, when you find bugs. We would welcome suggestions for the improvement of the program. The program can be downloaded at the CSJ ftp server. 
(a)

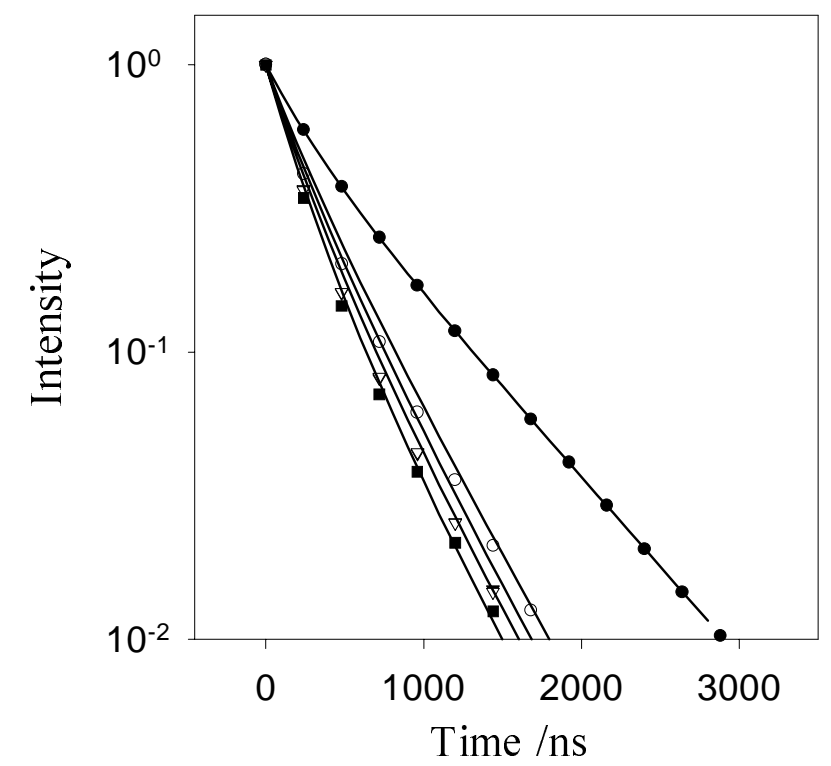

(b)

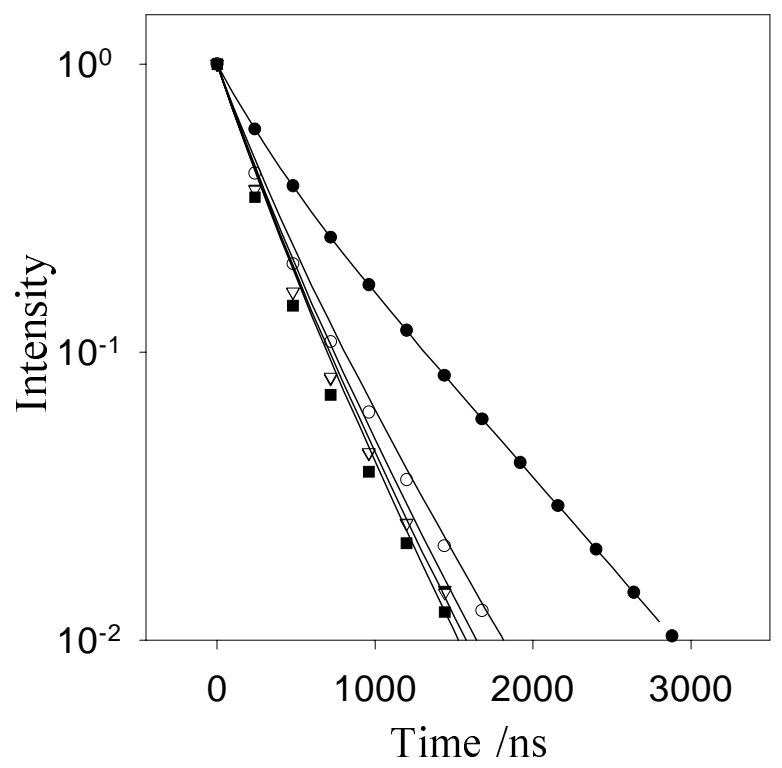

Figure 4. Emission decays of $\mathrm{Ru}(\mathrm{bpy}) 3^{2+}$ in polyethylene glycol at various $\mathrm{MV}^{2+}$ concentrations. Symbols: experimental, $\bullet, 0 \mathrm{~mol} \mathrm{dm}{ }^{-3} ;$,, $2.5 \mathrm{mmol} \mathrm{dm}^{-3} ; \mathbf{\nabla}, 5 \mathrm{mmol} \mathrm{dm}{ }^{-3} ; \nabla, 7.5 \mathrm{mmol} \mathrm{dm}^{-3} ; \mathbf{\square}, 10 \mathrm{mmol} \mathrm{dm}{ }^{-3}$. The curves are simulated with (a) Model 10 and (b) Model 6.

The authors acknowledge a Grant-in-Aid for JAERI's Nuclear Research Promotion Program (JANP) from Japan Atomic Energy Research Institute.

\section{References}

[1] M. Kaneko, Photoelectric Conversion by Polymeric and Organic Materials, Organic Conductive Molecules and Polymers, 4, ed. by H. S. Nalwa, John Wiley \& Sons, Ltd. (1997), 669.

[2] F. Ciardell, E. Tsuchida, and D. Wöhrle ed., Macromolecule-Metal Complexes, Springer-Verlag (1995).

[3] M. Yagi, Y. Takahashi, I. Ogino, M. Kaneko, J. Chem. Soc., Faraday Trans., 93(17), 3125 (1997).

[4] E. R. Carraway, J. N. Demas, B. A. Degraff, J. R. Bacon, Anal. Chem., 63, 337 (1991).

[5] M. Kaneko, T. Takekawa, T. Asakura, Makromol. Chem., Makromol. Symp., 59, 183 (1992).
[6] I. Klimant, O.S. Wolfbeis, Anal. Chem., 67, 3160 (1995).

[7] X.-H. Hou, M. Kaneko, A. Yamada, J. Polym. Sci., Polym. Chem. Ed., 24, 2749 (1986).

[8] M. Kaneko, X.-H. Hou, A. Yamada, Bull. Chem. Soc. Jpn., 60, 2523 (1987).

[9] M. Kaneko, S. Iwahata, T. Asakura, Photochem. Photobiol., 55 (1992).

[10] K. Nagai, N. Takamiya, M. Kaneko, J. Photochem. Photobiol. A:Chem., 84, 271 (1994).

[11] K. Nagai, N. Takamiya, M. Kaneko, Macromol. Chem. Phys., 197, 2983 (1996).

[12] O. Stern and M. Volmer, Phys. Z., 20, 183 (1919).

[13] F. Perrin, J. Perrin, C. R. Acad. Sci., Paris, 10, 1978 (1924).

[14] S.E. Mazzetto, I.M.M. Carvalho, M.H. Gehlen, J. Luminescence, 79, 47 (1998). 


\title{
不均一系における消光機構分析ソフトゥェアの開発
}

\author{
城石 英伸 $^{\mathrm{a} *}$, 鈴木 和久 ${ }^{\mathrm{a}}$, 瀬尾 美智子 ${ }^{\mathrm{a}}$, 時田 澄男 ${ }^{\mathrm{b}}$, 金子 正夫 ${ }^{\mathrm{a}}$ \\ $a$ 茨城大学理学部自然機能科学科, $\bar{\top}$ 310-8512 茨城県水戶市文京 2-1-1 \\ $\mathrm{b}$ 埼玉大学工学部応用化学科, $\bar{\top}$ 338-8570 埼玉県さいたま市下大久保 255 \\ *e-mail: cpx26485@mopera.ne.jp
}

さまざまな消光剂濃度における減衰曲線を 13 種類のモデルで解析するため, 減衰曲線 の消光斉の濃度に対する関数を導出し，GAUSS-NEWTON 法により解析するプログラム “QChanG4(QuenCHingANalyzerG4)”を作成した。同時に Stern-Volmer plotによる解析も行えるよう にし，不均一系における消光機構の解析が容易にできるようにした。また、ポリエチレングリコー ル中での Ru(bpy) $3^{2+}$ の発光の $\mathrm{MV}^{2+}$ による消光反応を研究した結果、消光機構は Model 10 によく 一致し、ポアソン分布型の静的消光と、動的消光の複合型の消光機構であることが明らかとなった。 また、この系においては二次消光速度定数が $2 \times 10^{8} \mathrm{M}^{-1} \mathrm{~s}^{-1}$ と水中と同程度に大きく、局部的な分 子運動が水中と同程度おこっていることが明らかとなった。

キーワード : Q-chanG4, 発光, 消光, 分析ソフトウェア, ポリエチレングリコール, メチルビオロゲン, トリス $(2,2$ 'ビピリジン) ルテニウム, 固相 